\title{
Effects of coal mining on the water resources in the communities hosting the Iva Valley and Okpara Coal Mines in Enugu State, Southeast Nigeria
}

\author{
I. I. Obiadi ${ }^{1}$ (D) C. M. Obiadi ${ }^{1}$ - B. E. B. Akudinobi ${ }^{1}$ - U. V. Maduewesi ${ }^{1}$ • \\ E. O. Ezim ${ }^{1}$
}

Received: 2 September 2015/Accepted: 28 April 2016/Published online: 7 May 2016

(C) Springer International Publishing Switzerland 2016

\begin{abstract}
Coal mining in the Enugu area of Nigeria has generated a lot of mine waste that has been dumped in landfills and surface dumps chosen for convenience and proximity to the waste source rather than environmental, geologic or engineering considerations. Environmental degradation and groundwater contamination has resulted. Structural analysis of the area shows that the geological formations are fractured with a dominant fracture strike in the E-W direction. These fractures, which are known to influence the flow direction of the rivers in the area, provide significant seepage pathways for contaminant transport. An azimuthal square array resistivity survey confirmed the presence of these fractures in the subsurface as well as their function as seepage pathways. Surface water resources and groundwater exploited from a shallow well has been shown to be contaminated with acidity, iron, and sulphate. The water must, therefore, be treated before consumption by the local inhabitants.
\end{abstract}

Keywords Enugu - Water resources management - Water contamination · Geology · Lithology

\section{Introduction}

Enugu, a densely populated metropolitan city, southeastern Nigeria (Fig. 1), owes its urban status primarily to the existence of very large deposits of coal (mainly of sub-bituminous grade) (Ezeigbo and Ezeanyim 1993; Egboka 1985). The city has served as the administrative capital of the old

I. I. Obiadi

izuchukwuig@yahoo.com

1 Department of Geological Sciences, Nnamdi Azikiwe University, Awka, Nigeria
Eastern region of Nigeria. The population of Enugu has continued to rise due to the existence and siting of large numbers of industries, factories and Government Secretariat that have attracted large number of workers and their dependents to the city.

A lot of coal mining activities have been done in Enugu area of Nigeria. Some of the coal mines established in Enugu include Udi Mines, Onyeama Mines, Okpara Mines, Iva Vally Mines and Ribadu Mines. Coal mining activities gave rise to a lot of mine waste which are dumped in landfills and surface dumps. The siting of these dumps was chosen for convenience and proximity to waste source rather than for environmental, geologic or engineering considerations, resulting in environmental degradation and potential groundwater contamination (Ezeigbo and Ezeanyim 1993). Most of the locals depend on the exploitation of groundwater through boreholes and shallow (hand-dug) well as well as the few surface water bodies in the area for domestic, agricultural and industrial purposes. This research aims to investigate the mine waste contaminant seepage pathways and the effects of the siting and spatial distribution of mine waste dumps on the environment and the water resources in the area, and also to provide background information for the proper planing of future dump sites. This is important as increased demand for alternative energy sources and Nigeria's quest for improved power supply has caused interest to be directed increasingly to the exploitation of the abundant coal resources in the country especially in the Enugu area.

\section{Regional tectonic and geologic setting of study area}

The study area is within the Anambra Basin in the Lower Benue Trough, Southeast Nigeria. The formation of the Benue Trough sedimentary basin followed the break-up 

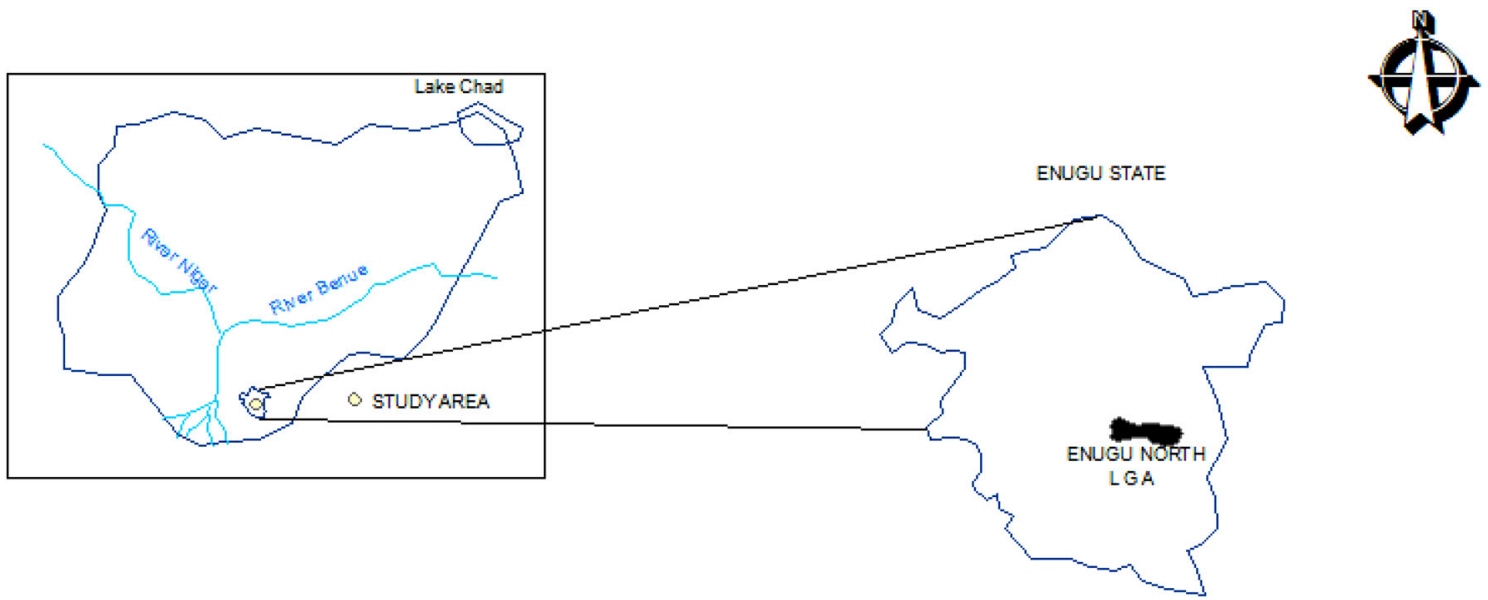

Fig. 1 Map of Nigeria showing study area in Enugu State

and separation of the South American and African continents in the Early Cretaceous. Three major tectonic cycles can be identified in southeastern Nigeria (Murat 1972). The first major tectonic phase (Aptian-Early Santonian) is related to the initial rifting and the opening of the Benue Trough. The second phase (Santonian-Early Campanian) was characterized by compression tectonics resulting in the folding and uplift of the Abakaliki Anticlinorium, the subsequent formation of the Anambra Basin and the complimentary Afikpo Syncline. The third phase (Late Campanian-Eocene) involved rapid subsidence and uplift in alternation with subsequent progradation of a delta and deposition of Anambra Basin sedimentary fill. The Anambra Basin is a Cretaceous depocentre that received Campanian-Tertiary sediments. The sedimentary formation in the Anambra Basin is summarized in Nwajide 2013.

\section{Coal geology and occurence}

The coal deposit in Enugu area is mainly of sub-bituminous grade, black to brownish black in colour and is estimated at over 80 million tonnes (Kogbe 1974). The coal outcrops along the Enugu escarpment, road cut, mine sites and gullies. The coal bearing formations in the Anambra Basin are the Mamu Formation and the Nsukka Formation formally referred to as the lower coal measures and upper coal measures, respectively.

The Mamu Formation consists essentially of finegrained sandstone, shale, mudstone and sandy shales with several coal seams. The thickness of the coal seam varies from a few centimeters to about $2 \mathrm{~m}$. The Mamu Formation marks the regressive phase of the Upper Campano-Maastrichtian transgressive cycle (Obaje 2009). Palaeoenvironmental studies indicate that the formation was deposited in shallow fresh water to paralic, medium to low-energy environment.
The lithology of the Nsukka Formation is very similar to that of the Mamu Formation and consists of an alternating succession of sandstone, dark shale and sandy shale, with few relatively thin coal seams at various positions in the lower horizons. Thin limestone occurs at the top of the sequence. Palaeoenvironmental studies indicate that the formation was deposited under paralic condition which prevailed during the second Post-Santonian transgressive cycle.

\section{Methodology}

\section{Surface geological field mapping and analysis}

A detailed surface geological field mapping was carried out to locate and describe coal/rock outcrop and their field relations, and also to produce a geologic map of the area. This is important because the surface geology has a direct effect on the way and manner mine waste contaminants are dispersed and leached into the subsurface. For example, contaminants from mine wastes disposed on sandstone lithology are readily leached into surface water and groundwater bodies due to the relatively porous and permeable nature of sandstone when compared to shale lithology. Several representative outcrops were visited and described (Figs. 2, 3); using basic field mapping methods of traversing across regional dips, outcrop mapping and description, and contact tracing, a geologic map of the area was produced (Fig. 4). Three lithostratigraphic formations-the Enugu Shale, Mamu Formation and the Ajalli Formation-were found to underlie the study area (see Fig. 4). Outcrops in the study area include the Enugu escarpment, road cut, mine site excavation, gully site and river/stream banks.

Structural mapping and analysis was also done. Geological structures such as fractures (joints and faults) 
Fig. 2 Lithology of the Mamu Formation described from a river bank exposure close to the Iva Valley coal mines

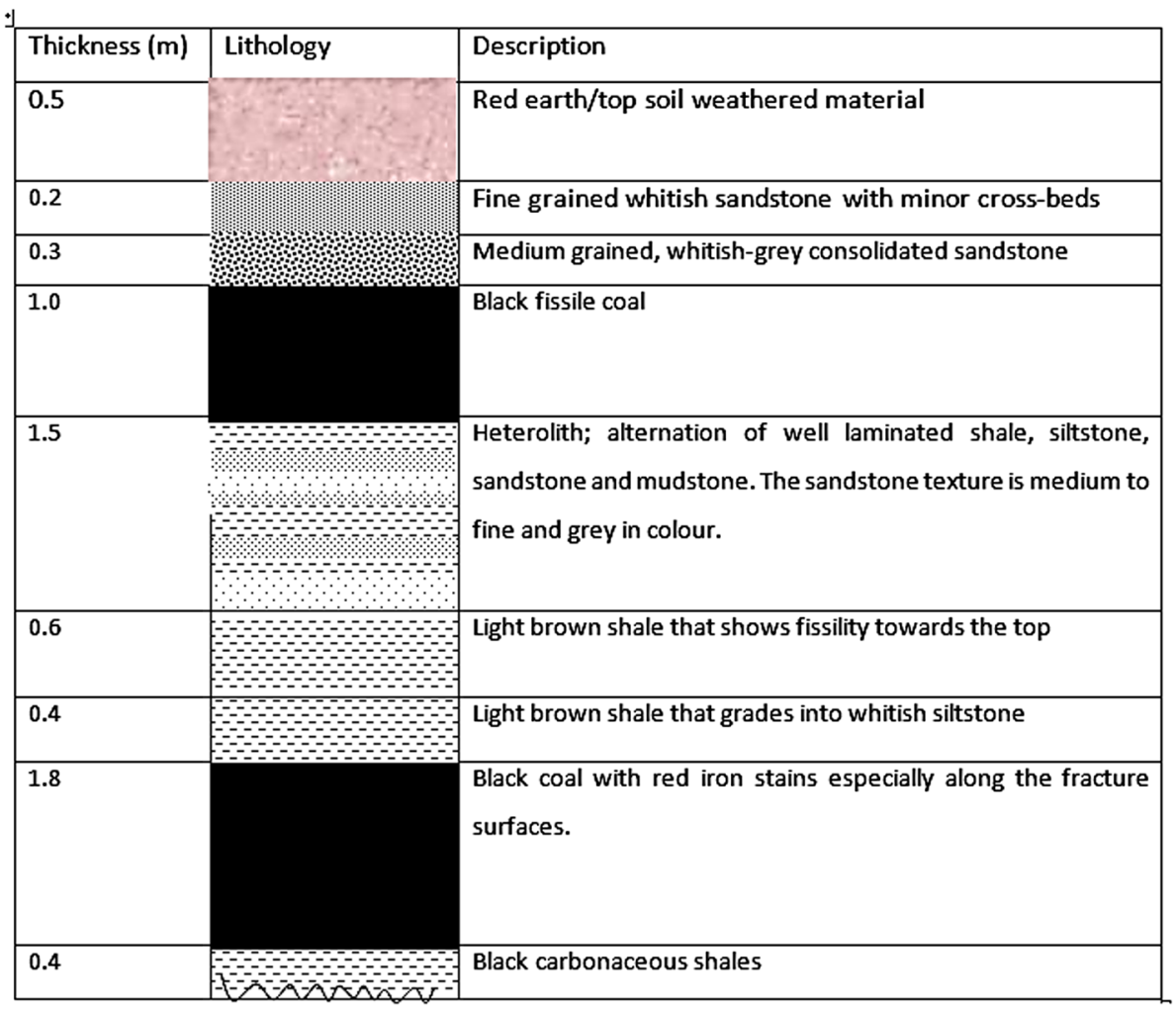

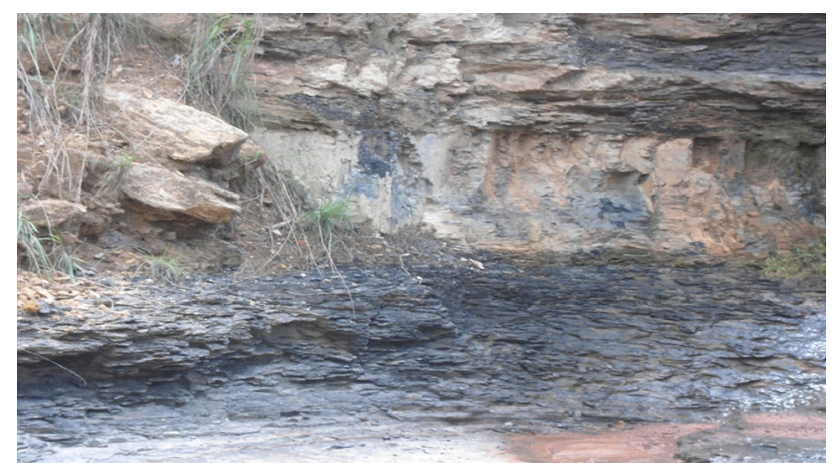

Fig. 3 A section of the Manu Formation exposed at a river bank and from which the lithology in Fig. 2 was described

enhance the porosity and permeability of rocks; and also form ready conduit for fluid and contaminant transport especially when primary porosity and permeability are poor. Structural mapping showed that the rocks in the study area are fractured with the highest fracture density found in the units of the Mamu Formation. A careful study and analysis of the fractures show that the dominant trend of these fracture is in a more or less east-west direction, with some minor fractures in other orientations connecting the fractures in the dominant orientation (Fig. 5a).

This dominant fracture trend corresponds with the trend and flow direction of the rivers and streams in the study area suggesting fracture-controlled flow pattern of the surface water bodies. The aperture width of the fracture varies and is significant. Some of the fractures have been filled in by secondary materials. However, almost all the fractures observed show iron stains/precipitates, indicating that they are ready pathways for fluid transport. The dominant trend of the fracture is presented in the rose diagram below (Fig. 5b).

Grain size distribution analysis done on several representative samples systematically collected at various horizons and spatial locations shows that the sandstone units of the Mamu Formation are fine-medium grained and moderately sorted; while the Ajalli Sandstone is populated by fine-medium-coarse grain sizes in an upward coarsing sequence, and are poorly sorted. This has implication for primary porosity and permeability, and by extension the ability for the rock unit to transport contaminant species (for details on the computation and significance of the grain size distribution parameter the reader is referred to Folk and Ward 1957).

\section{Geophysical survey and analysis: the azimuthal square array resistivity survey}

Azimuthal resistivity survey was carried out to measure the directional variation of resistivity with azimuth. Fractures, which act as conduit for fluid and contaminant transport, contribute to azimuthal resistivity variation by creating 


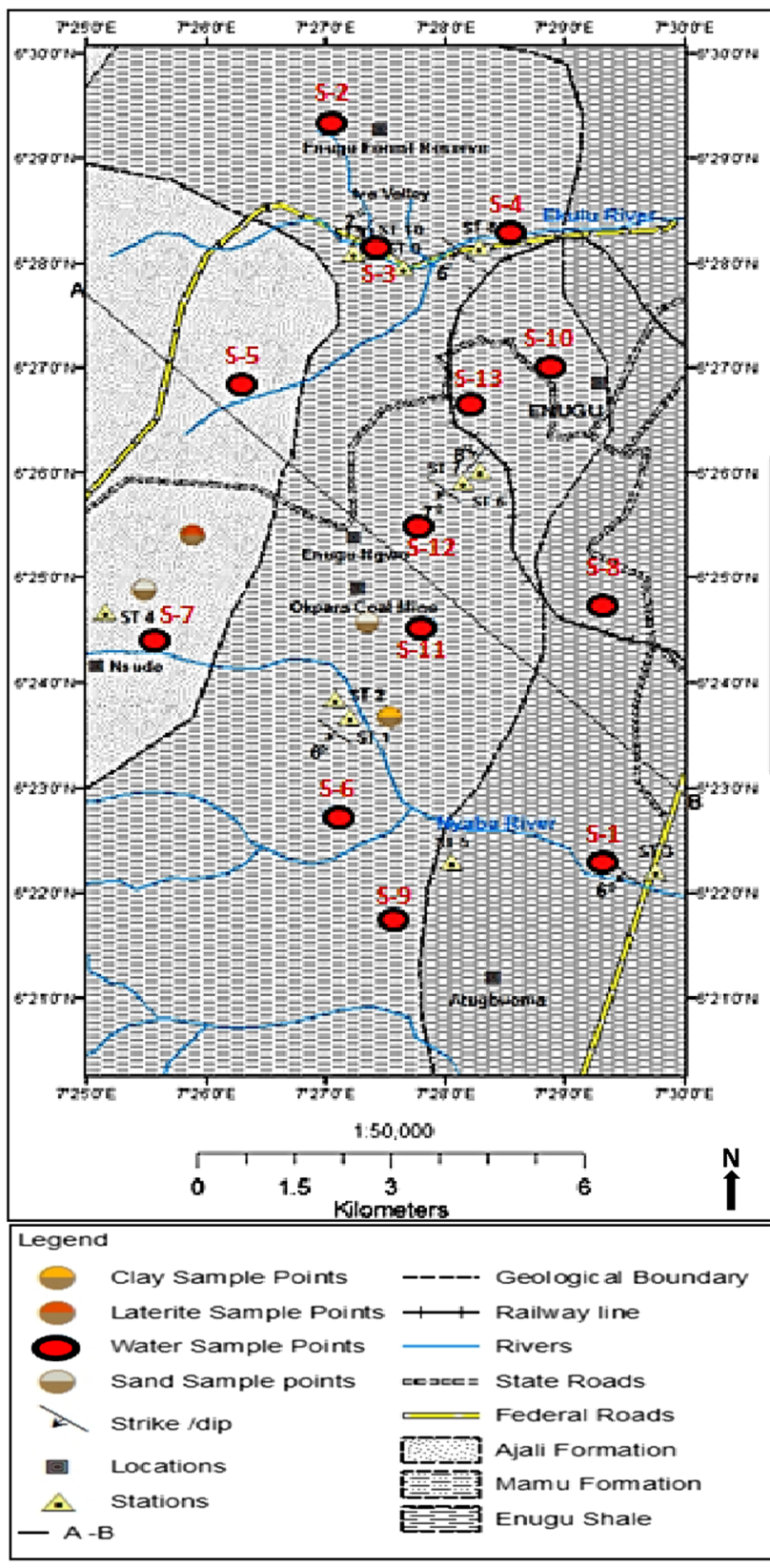

Fig. 4 Geologic map of study area showing the boundaries of the formations and the position of the water sampling points

zones of contrasting electrical properties in the bedrock and thereby increasing hydraulic and electrical conductivity along the direction of fracture strike while decreasing same at direction perpendicular to it (Obiadi et al. 2013). The azimuthal resistivity survey using the square array (Habberjam 1967) was done by rotating the whole electrode array through $180^{\circ}$ at regular increments starting with an initial array orientation aligned in the direction of true north.

Using a fixed electrode spacing of $20 \mathrm{~m}$, measurements along different azimuths were taken by progressively rotating the square array setup about its centre at angular increment of $22.5^{\circ}$ through $157.5^{\circ}$. Several surveys were carried in the study area and the polar plots of the survey data produced.

Using the azimuthal square array resistivity survey method, the azimuth of existing fractures zones (and likely seepage pathway) is generally indicated by a decrease in resistivity along that particular azimuth relative to the others. Hence, plots of apparent resistivity values as a function of azimuth are used to characterize electrical anisotropy. Circular plots are characteristically interpreted to indicate electrical isotropy, suggesting the absence of measurable fracture set of preferred orientation, or small volume of rock investigated (Busby and Peart 1997). On the other hand, elliptical plots are generally construed to signify anisotropic response within the rock mass. With the square array, the orientation of the dominant fracture trend is defined and interpreted as the orientation of the minor axis of the ellipse fitted to the polar plot. Visual inspection of the ellipse fitted to the polar plots (Fig. 6) showed that the fracture trend is approximately NW-SE and this compares well with the fracture trend mapped at the surface (Fig. 6).

\section{Water resources and hydrogeochemistry}

Surface water and groundwater samples were collected systematically in the study area and analysed. The major surface water bodies in the area include the Ekulu River, Nyaba River, Orubu River, Otukponu and Sewa streams. Groundwater is extracted from boreholes and shallow well which target mainly the two major aquifers in the area (Ezeigbo and Ezeanyim 1993). In all, thirteen (13) samples were collected for analysis. Samples 1-6 are from surface water sources (river, stream and spring), while Samples 7-10 and 11-13 are from water boreholes and shallow water well, respectively; both groundwater sources. The samples were collected in clean bottles, well preserved and analysed within $48 \mathrm{~h}$. The result of the hydrogeochemical analysis is presented in Table 1.

\section{Results and discussion}

\section{Seepage pathway determination from geological and geophysical studies}

An important physical feature of sedimentary rock is the presence of interstitial pore spaces or primary porosity, and permeability. Porosity and permeability depend on many factors such as grain size, shape and arrangement; and sorting. Generally rocks with clay-size grains, such as shale and mudstone, are less permeable than rock like sandstone 
a

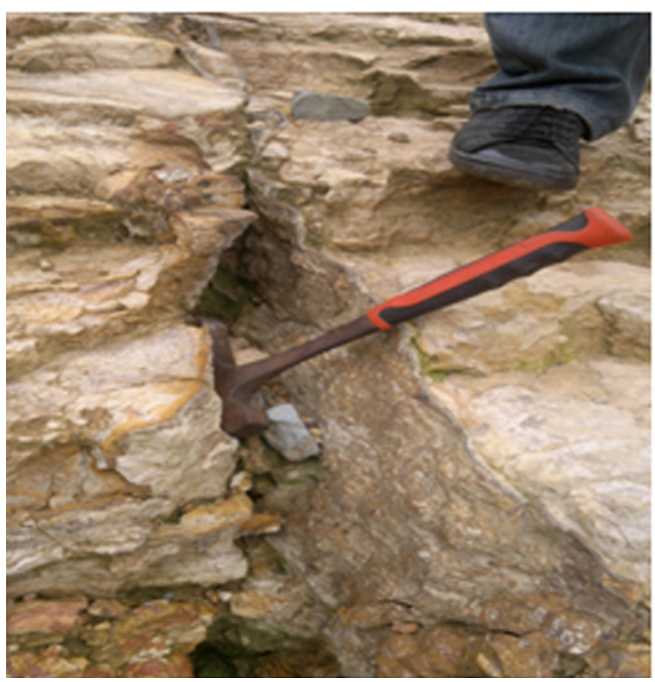

b

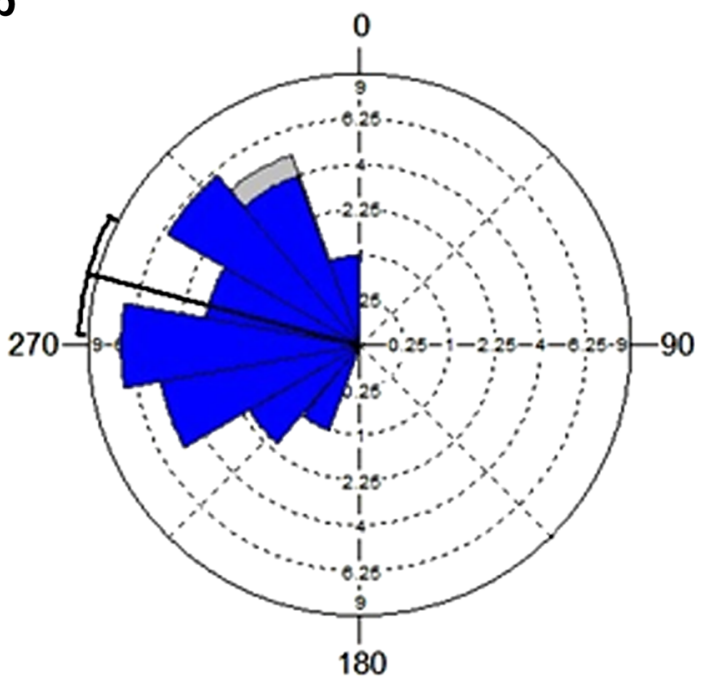

Fig. 5 Fracture in the outcrop of Mamu Formation (a) and rose diagram showing dominant fracture trend in the study area (b)

Azimuthal Resistivity Plot 1

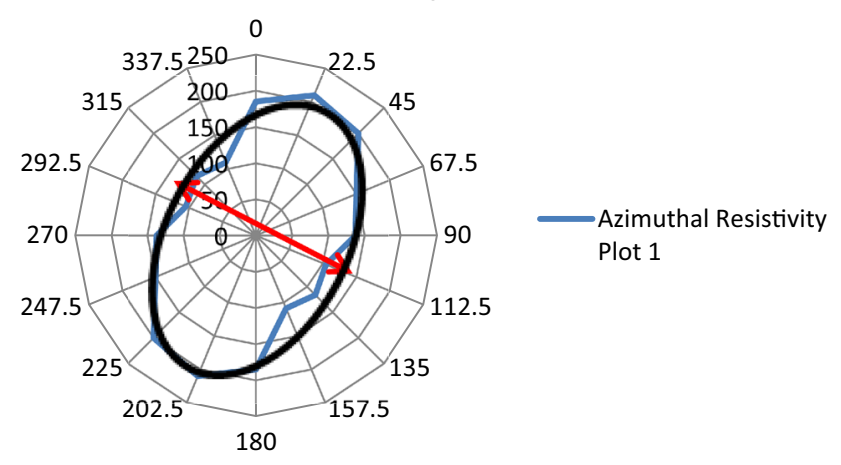

Fig. 6 Azimuthal polar plot fitted with an ellipse and an arrow indicating the dominant fracture (and possibly seepage pathway) trend orientation

with sand-size grains. Fractures in rocks enhance porosity and permeability, creating pathways for fluid flow while also enhancing contaminant flow.

The study area is underlain by three lithostratigraphic formations-the Enugu Shale, Mamu Formation and Ajali Sandstone. Field studies and outcrop descriptions show the following: the Enugu Shale comprises mainly shales and highly compacted and indurated mudstones which are lithologies with relatively poor permeability; the Mamu Formation comprises fine-grained sandstones, siltstone and shales; while the Ajali Sandstone consists of fine-mediumcoarse-grained friable sandstones of relatively good permeability. Grain size distribution analysis showed that the sandstone members of the Mamu Formation are fine grained and well sorted while that of the Ajali Sandstone is fine-coarse grained and poorly sorted. This suggest that the Enugu Shale is relatively less permeable and hence less likely to conduct the flow of contaminant species from the coal mine activities through its interstitial pore spaces but the fractures in it may form pathway for contaminant transport. On the other hand, interstitial pore spaces in the relatively porous and permeable sands of the Mamu Formation and Ajali Sandstone readily form seepage pathway for contaminant transport. The fractures in these two formations will greatly enhance contaminant transport. Structural mapping and analysis showed that the three formations are fractured with the highest fracture density in the Mamu Formation. The dominant fracture strike is in the E-W direction. These fractures in no small measures influence the flow of fluid (and by extension contaminant species) in the study area as is evidenced in the surface drainage flow pattern which appears to be fracture controlled and in the direction of the dominant fracture strike. The result of the azimuthal square array resistivity survey lends credence to this as a significant decrease in resistivity was recorded in the orientation of the dominant fracture strike relative to other azimuths or trends, suggesting the presence and flow of conducting fluids (possibly coal mine contaminants) along that azimuth, and within and around these fractures.

\section{Coal mining activities, geochemical characterization, hydrogeochemistry and water quality}

Coal mining has been a major economic activity in and around the Enugu metropolis though coal has been religated by oil as the major source of energy resulting in the decline and eventual cessation of commercial coal mining activities and production. Increased demand for alternative 
Table 1 Hydrogeochemical data for samples collected in study area compared against WHO portable water standard

\begin{tabular}{|c|c|c|c|c|c|c|c|c|c|c|c|c|c|c|}
\hline \multirow{2}{*}{$\begin{array}{l}\text { Hydrogeochemical } \\
\text { parameter }\end{array}$} & \multirow{2}{*}{$\begin{array}{l}\text { WHO } \\
\text { standard }\end{array}$} & \multicolumn{13}{|c|}{ Samples } \\
\hline & & S-1 & $\mathrm{S}-2$ & $\mathrm{~S}-3$ & S-4 & S-5 & S-6 & S-7 & $\mathrm{S}-8$ & S-9 & $\begin{array}{l}\text { S- } \\
10\end{array}$ & $\begin{array}{l}\text { S- } \\
11\end{array}$ & $\begin{array}{l}\text { S- } \\
12\end{array}$ & $\begin{array}{l}\mathrm{S}- \\
13\end{array}$ \\
\hline $\mathrm{pH}$ & $6.5-8.5$ & 4.58 & 5.04 & 2.8 & 6.08 & 5.5 & 6.24 & 5.9 & 6.5 & 6.8 & 5.8 & 4.5 & 4.9 & 4.4 \\
\hline Sulphate $(\mathrm{mg} / \mathrm{l})$ & 250 & 82.3 & 246.9 & 680 & 205.8 & 246.9 & 488.1 & 2.02 & 7.51 & 4.45 & 1.88 & 233 & 12 & 81 \\
\hline Chloride (mg/l) & 250 & 15 & 14 & - & 19 & 18 & 9 & 2 & 3 & 3.12 & 1.5 & 4.1 & 5.3 & 26 \\
\hline $\begin{array}{l}\text { Total dissolved solid } \\
(\mathrm{mg} / \mathrm{l})\end{array}$ & 500 & 0 & 0.3 & 882 & - & 1 & - & 19.02 & 49 & 44 & 16 & 358 & 54 & 177 \\
\hline Carbonate & 500 & 75 & 90 & 1.02 & 4.5 & 10 & - & 7.4 & 20 & 20.1 & 8.1 & 230 & 30 & 119 \\
\hline Nitrate $(\mathrm{mg} / \mathrm{l})$ & 50 & 0.58 & 0.215 & 5.3 & 0.11 & 0.92 & 0.98 & 2.14 & 7.8 & 11.4 & 2.22 & 0.25 & 25.7 & 35.9 \\
\hline Iron $(\mathrm{mg} / \mathrm{l})$ & 0.3 & 0.04 & 0 & 12.62 & 0.782 & 4.026 & 0.467 & 0.19 & 0.07 & 0.05 & 0.18 & 1.15 & 1.17 & 1.3 \\
\hline Calcium (mg/l) & 200 & 12.557 & 1.123 & 81 & 1.913 & 2.317 & 0.993 & 1.21 & 3 & 3.8 & 1.2 & 51 & 5.5 & 17.5 \\
\hline Sodium (mg/l) & 200 & 3.6732 & 0.9532 & 6.9 & 3.4579 & 1.0667 & 2.022 & 1.3 & 2.6 & 3 & 1.21 & 4.2 & 3.5 & 14.7 \\
\hline Magnesium (mg/l) & 150 & 10.632 & 2.9504 & 105 & 4.3417 & 9.3848 & 1.7847 & 1.24 & 2.5 & 3.7 & 1.25 & 22 & 4.1 & 16.2 \\
\hline Potassium (mg/l) & N/A & 0.6962 & 0.1007 & 2.4 & 1.1041 & 2.1092 & 0.0169 & 1.3 & 1.5 & 1.1 & 1.3 & 4.2 & 4 & 8.6 \\
\hline Manganese (mg/l) & 0.4 & 2.164 & 0 & 2.82 & 0.036 & 2.144 & 9.843 & 0.05 & 0.04 & 0.01 & 0.05 & 0.21 & 0.11 & 0.16 \\
\hline
\end{tabular}

Significantly high values are highlighted in italics while values outside WHO standard highlighted in bold

energy sources and Nigeria's quest for improved power supply have caused interest to be directed increasingly towards the exploitation of the abundant coal resources in the country especially in the Enugu area. Coal mining and milling removes the overburden materials and exposes mine spoils to oxidation. Enugu coal deposits as with most others coal deposits are associated with pyrite and marcasite which is stable below water table environment but is oxidized if exposed or the water table is lowered (Ezeigbo and Ezeanyim 1993; Ememcheta 2013).

Oxidation of pyrite (sulphide mineral) produces sulphuric acid which renders the water corrosive and lowers $\mathrm{pH}$ values (acidity). This can be illustrated by the general equation according to Stumm and Morgan (1996):

$\mathrm{Fe}_{2}+\mathrm{H}_{2} \mathrm{O}+3 \frac{1}{2} \mathrm{O}_{2} \leftrightharpoons \mathrm{FeSO}_{4}+\mathrm{H}_{2} \mathrm{SO}_{4}$

Further oxidation of ferrous sulphate produces ferric sulphate according to the relation (Singh and Mridula 1985; Utom et al. 2013):

$\mathrm{Fe}_{2}\left(\mathrm{SO}_{4}\right)_{3} \leftrightharpoons 2 \mathrm{Fe}^{3+}+3 \mathrm{SO}_{4}^{2-}$

$\mathrm{Fe}^{3+}$ can thus be hydrolysed

$\mathrm{Fe}^{3+}+3 \mathrm{H}_{2} \mathrm{O} \leftrightharpoons \mathrm{Fe}(\mathrm{OH})_{3}+3 \mathrm{H}^{+}$

resulting in acidity and iron hydroxide formation.

Carbonate rocks occur as units in the Mamu Formation hosting the coal seams. The acidity produced by the oxidation of the sulphide minerals promotes the weathering of the carbonate minerals in the host rocks and the coal mine waste, leading to increase in total hardness (a measure of the concentration of divalent cations $\mathrm{Ca}^{2+}$ and $\left.\mathrm{Mg}^{2+}\right)$ in water bodies according to the equations (Hem 1985):

$\mathrm{CaCO}_{3}+\mathrm{H}^{+} \leftrightharpoons \mathrm{Ca}^{2+}+\mathrm{HCO}_{3}^{-}$

$2 \mathrm{CaMg}\left(\mathrm{CO}_{3}\right)+2 \mathrm{H}^{+} \leftrightharpoons 2 \mathrm{Ca}^{2+}+2 \mathrm{Mg}^{2+}+2 \mathrm{HCO}_{3}^{-}$

Acid mine drainage AMD pollution which results from coal mining activities has been a major problem affecting the chemical quality of both surface and groundwater resources within Enugu. Streams/spring issuing out of mine tunnels where it intercepts water table flows through exposed coal seams and bedrock (Fig. 7), and also over and around mine waste dump into surface water bodies and groundwater recharge area. Most of these mine waste dumps are sited in areas chosen for convenience and proximity to waste source rather than from hydrogeologic, environmental, geologic or engineering considerations (Fig. 7). This gave rise to environmental degradation and surface water and groundwater contamination with attendant health implications to the local populace.

Thirteen surface water and groundwater samples were collected from the study area and analysed. Samples 1-6 are from surface water sources (river, stream and spring), while Samples 7-10 and 11-13 are from water boreholes and shallow water well, respectively, both groundwater sources. Sample 1 was collected from the Nyaba river which is relatively far removed from the Okpara Coal Mine (see Fig. 4). Samples 2 and 3 were taken from a stream which flows across the Okpara Coal Mine; however, while Sample 2 was collected upstream before the stream comes 

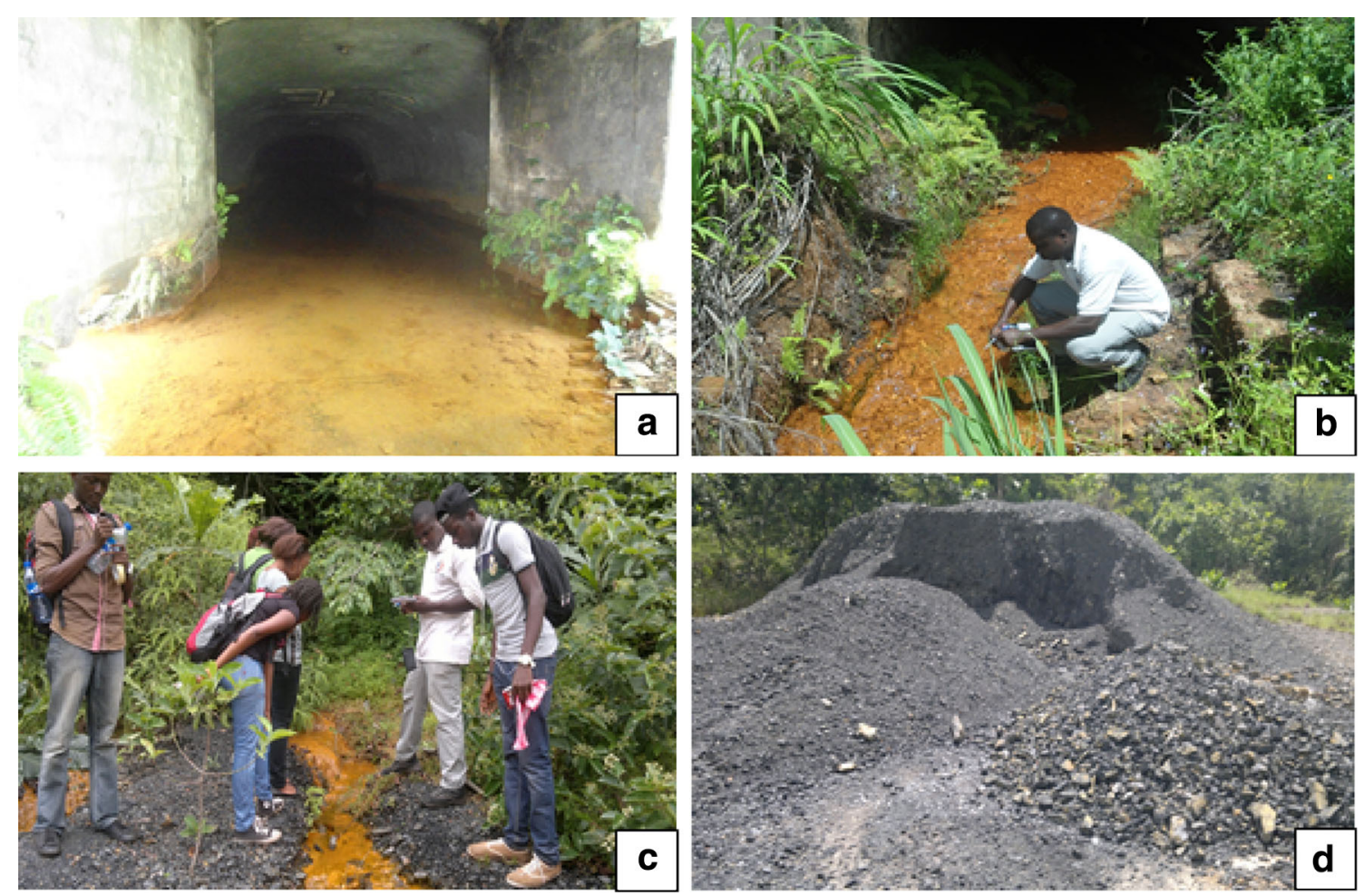

Fig. 7 Water flowing out of a mine tunnel which intercepts the water table at the Iva Valley coal mine (a, b) through and over surface mine waste dump site (c) scattered indiscriminately over the study area (d)

in contact with and crosses the coal mine site/waste dumps, Sample 3 was collected downstream after contact with the mine site/waste dumps. Samples 4 and 5 were collected from streams flowing close to the Iva Valley Coal Mine, north of the study area while Sample 6 was from Mmiri Ocha river which joins the Nyaba river to the west. The groundwater samples (Samples 7-13) were collected from boreholes and shallow water wells constructed by government and development partners (Millennium Development Goal MDG projects), and private individual scattered around the study area. The results of the hydrogeochemical analysis done on the samples are presented in Table 1.

\section{pH}

Only two (2) out of the thirteen (13) samples analysed have $\mathrm{pH}$ values within the permissible limits of World Health Organization WHO, while others presented low (acidic) $\mathrm{pH}$ values with Sample S-3 having a very low value of 2.8 (Table 1). Oxidation of pyrite and marcasite minerals (Eqs. 1-3) produces acid which lowers $\mathrm{pH}$. Low $\mathrm{pH}$ recorded in the water samples analysed in the study area can also be attributed to the influence of the acid mine drainage and possible acidic lateritic soil, forestry activity, acid precipitation, and fulvic and humic soils (Gray 1996; Raghunath et al. 2001). Low pH, which is indicative of acidity give water a sour taste, renders it corrosive and also increases weathering of carbonate rock minerals (Eqs. 4, 5). This perhaps explains the observed trend in the variation of the distribution of ionic species in the surface water and groundwater samples. Surface water samples, which are relatively prone to AMD contamination and have a relative low $\mathrm{pH}$, have distribution trend for anions and cations given as $\mathrm{SO}_{4} \rightarrow \mathrm{HCO}_{3} \rightarrow \mathrm{Cl} \rightarrow \mathrm{NO}_{4}$ and $\mathrm{Mg} \rightarrow \mathrm{Na} \rightarrow \mathrm{Ca} \rightarrow \mathrm{K}$; while the groundwater samples gave $\mathrm{HCO}_{3} \rightarrow \mathrm{NO}_{3} \rightarrow$ $\mathrm{SO}_{4} \rightarrow \mathrm{Cl}$ and $\mathrm{Ca} \rightarrow \mathrm{Mg} \rightarrow \mathrm{Na} \rightarrow \mathrm{K}$, respectively.

\section{Sulphate}

Two samples presented sulphate values high above the WHO standard: Sample S-3 with value of $680 \mathrm{mg} / \mathrm{l}$ and Sample S-6 with value of $488.1 \mathrm{mg} / 1$ (Table 1 ; Fig. 8). Sulphate ions are products of the oxidation of minerals such as pyrite which are found in association with coal in the Enugu area. High solubility of the sulphate ions makes it easily leached, and perhaps responsible for these high values recorded in the samples. High sulphate ion values in excess of $250 \mathrm{mg} / \mathrm{lmay}$ have laxative effects (Ezeigbo and Ezeanyim1993).

\section{Iron and manganese}

Seven (7) samples presented values significantly above the WHO permissible limits for iron while four (4) samples 


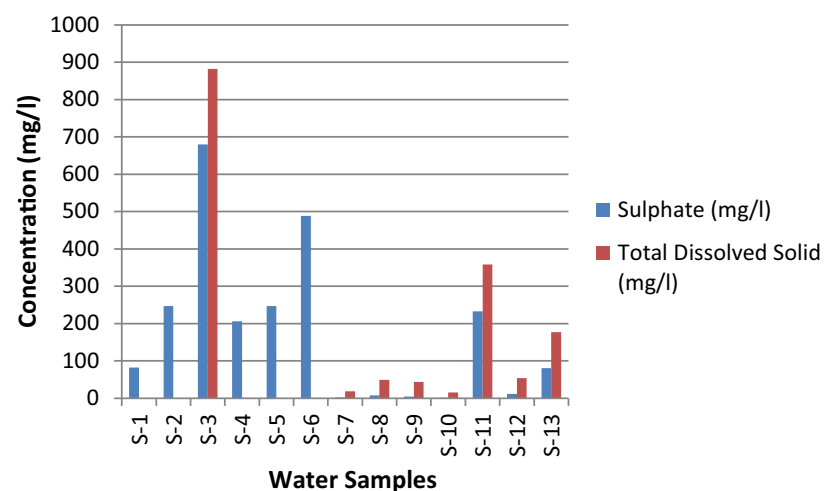

Fig. 8 Sulphate and total dissolved solids distribution in water samples of the study area

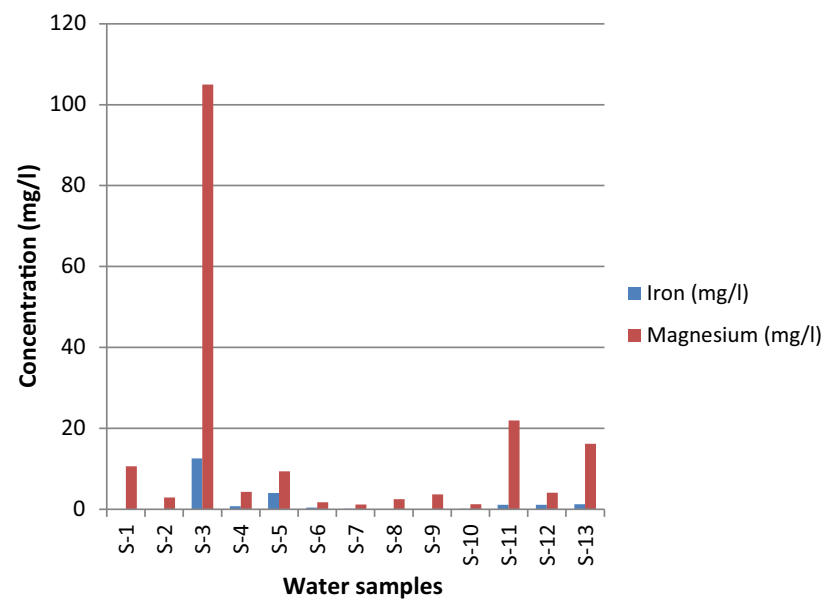

Fig. 9 Distribution of iron and magnesium in water samples of the study area

have values for manganese above WHO standard (Table 1; Fig. 9). Iron is a common component of coal mine drainage which can have a detrimental effect on human, animals and aquatic life as well as reduces the suitability of contaminated water for domestic, agricultural and industrial uses (Earle and Callaghan 1998). The high iron value may be largely due to the presence of abundant pyrite in the coals and rocks of the study area. Manganese is another metal that is widely distributed in mine drainage. Manganese can be present in a variety of forms and compounds, and complexes with organic compounds. Neurological disorder is one of the negative health implications of high manganese concentration in water consumed by humans.

\section{Surface water resources versus groundwater resources}

Surface water resources are harnessed by the locals from rivers, streams and springs with the major ones being the Ekulu River and Nyaba River, and their distributaries;

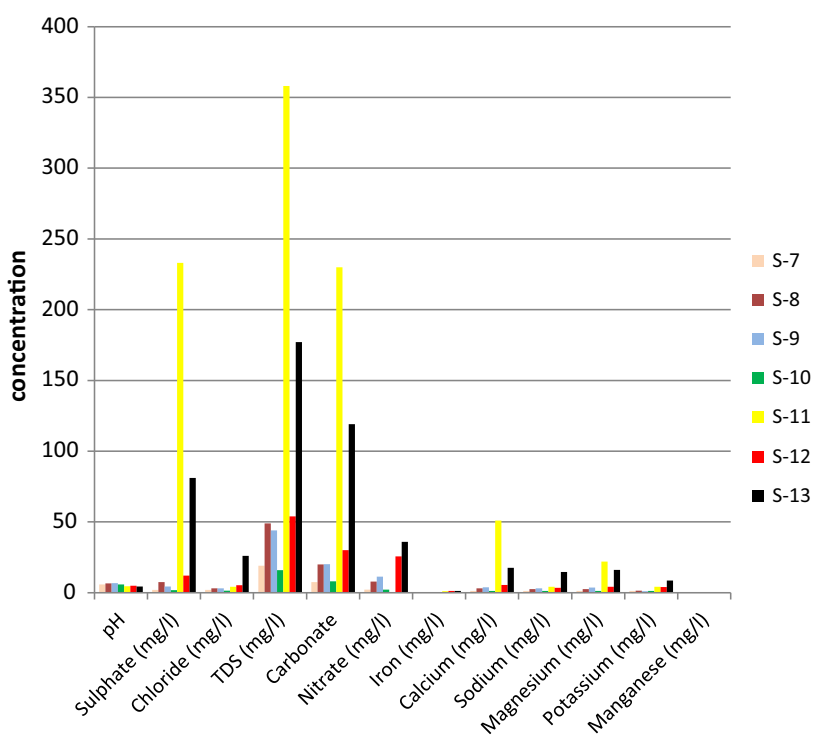

Fig. 10 Distribution of some geochemical species in borehole (S-7 to S-10) and shallow well (S-11 to S-13) water samples in the study area

while the groundwater resources are harnessed through boreholes and shallow well scattered all over the area. These water sources are used by the local residents for various needs ranging from domestic to agricultural and industrial. The inhabitants depend more on surface water sources than groundwater sources as there are quite few boreholes and shallow wells in the area. The few boreholes available maybe due to economic and geological constrains resulting from the peculiar geology of the area. Hydrogeochemical analysis of the samples collected from surface water sources and groundwater sources show that the groundwater sources are of relatively better quality when compared against the surface water sources.

All the surface water samples (Samples 1-6 in Table 1) have low $\mathrm{pH}$ well below WHO limits. This is also the case for shallow well water samples (Samples 11-13 in Table 1); while only two borehole water samples presented low pH. All the borehole samples (Samples 7-10) gave iron values which are within the WHO limits while all the shallow wells and majority of the surface water samples presented values outside and above the WHO limits. Manganese is found to be in concentrations well above the WHO limits in all but two (2) of the surface water samples while all the groundwater samples presented values below and within the WHO permissible limits.

Generally, groundwater supply is found to be of better quality when compared to surface water supply. Also groundwater exploited from boreholes is of better quality than those from shallow wells (Fig. 10). The reason for this may be due to direct contamination of the surface water and shallow well supply by the coal mining activities which exposes coal, minerals and lithologies to surface 


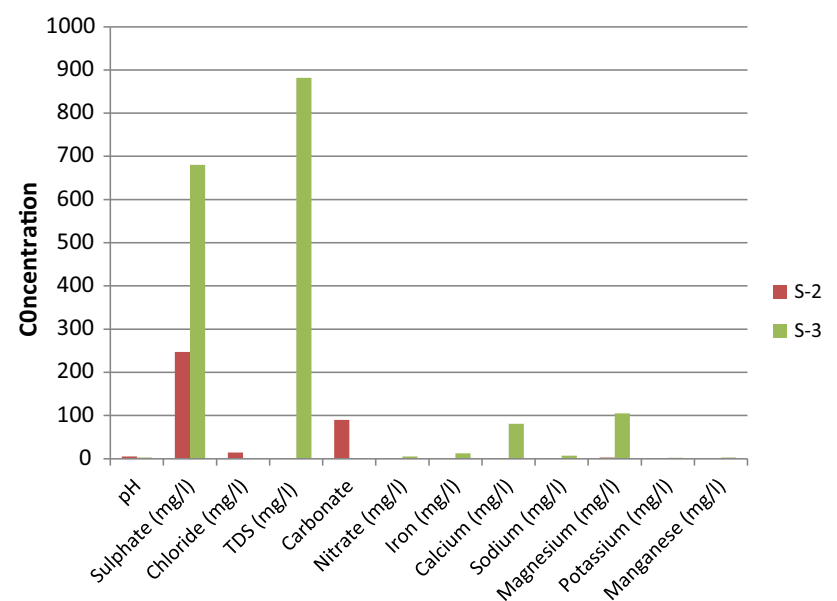

Fig. 11 Distribution of geochemical species in Samples S-2 and S-3 collected from the same stream but at different locations

oxidation and leaching. This has health and socio-economic implications for local inhabitants.

\section{Sample 2 (S-2) versus Sample 3 (S-3)}

Samples 2 and 3 (Table 1) were collected from the same stream but from different locations. In between the two sample locations lies the Okpara Coal Mine/mine spoils dump. Sample 2 was collected 'upstream' while Sample 3 was collected 'downstream' after and beyond the mine and dump site over which the stream flowed and had contact. The effect of the coal mine and dump site on the hydrogeochemistry and water quality of surface water resource is very striking and evident in the contrasting chemistry of these water samples of the same stream but collected from different locations (Fig. 11). While Sample 2 is of a relatively better quality except for the slightly low $\mathrm{pH}$ value of 5.04 , Sample 3 is of very poor quality with very low $\mathrm{pH}$ value of 2.8 (high acidity), high total dissolved solids TDS of $882 \mathrm{mg} / \mathrm{l}$, and high iron and manganese values of 12.62 and $2.82 \mathrm{mg} / \mathrm{l}$, respectively, which are outside the WHO permissible limits. Calcium and magnesium values analysed from Sample 3, though below WHO limits are significantly high (81 and $105 \mathrm{mg} / \mathrm{l}$, respectively) when compared against values obtained from Sample 2.

\section{Conclusion and recommendations}

Coal mining activities in Enugu area gave rise to a lot of mine waste which are dumped in landfills and surface dumps chosen for convenience and proximity to waste source rather than from environmental, geologic or engineering considerations, giving rise to environmental degradation and groundwater contamination/pollution.
Surface geological mapping showed that the study area is underlain by three lithostratigraphic formations-the Enugu Shale, Mamu Formation and Ajali Sandstone. While the Enugu Shale and the Ajali Sandstone comprises mainly shale and sandstone, respectively, the Mamu Formation consists of shales, siltstone and sandstones. Grain size distribution analysis showed the sandstone units of the Mamu Formation and the Ajali Sandstone to be moderately sorted and poorly sorted, respectively. This has implications for porosity, permeability and seepage pathway/contaminant transport. Structural analysis shows that the formations are fractured with a dominant fracture trend in the $\mathrm{E}-\mathrm{W}$ direction. These fractures which influence the flow direction of the rivers in the area significantly form seepage pathways/conduit for contaminant transport. Azimuthal square array resistivity survey confirms the presence of these generally E-W trending fractures in the subsurface as well as their function as seepage pathways. Water quality has been greatly affected by the coal mining activities in the area. Water pollution has perhaps resulted from the exposure and oxidation of pyrite $\left(\mathrm{FeS}_{2}\right)$ and other sulphide minerals in the coal and adjacent lithologies, yielding soluble iron, sulphate and acidity. Geochemical characterization which showed the predominance of $\mathrm{Ca}$, $\mathrm{Mg}, \mathrm{SO}_{4}$ and $\mathrm{HCO}_{3}$, which are weathering products of carbonate minerals in the rock units of the formations in the study area (Eqs. 4, 5), also suggests significant influence of geology/lithology on hydrochemistry and water quality. This has affected more of the surface water resources and groundwater exploited from shallow well. The water must be, therefore, treated before consumption by the local inhabitants to protect the health of the consumers. However, the following recommendations are important:

- The mine waste dumps that are presently scattered all over the abandoned mine site and exposed to surface oxidation conditions should be properly disposed to arrest further water and environmental degradation.

- With renewed interest in coal mining activities for power production, subsequent mine waste dumps should be properly and scientifically disposed with respect to the geology and chemistry of the area and waste type. The waste should be disposed in landfills/ underground to avoid surface chemical reactions and contamination of environment and surface water resources; and since fractures and primary porosity/ permeability serve as seepage pathways the landfills should be sited in the Enugu Shale units where it may be contained since this formation is the least fractured and porous/permeable. This "favourable" area has been mapped and illustrated in the geologic map produced.

- Better, appropriate and efficient mining and waste disposal methods, such as dry cover method, that are 
environment friendly should be employed in the proposed new mining campaign. Mining programs should be well planned and approved by the appropriate authorities; and illegal mining prohibited.

- Public portable water schemes should be revived in the area to serve the water needs of the locals. Surface water resources should be well treated and piped to homes and other service points to stop the local inhabitants from consuming the contaminated water. Water from the Ninth Mile Corner-Ngwo Borehole Field/Network can also be piped to this area for use as the water quality is better in these far-removed areas.

- Stakeholders in the water, environment and mining sectors should be educated/enlightened on the impact of coal mining and better ways of ameliorating its effect. This can be achieved by way of training, seminars, workshops and conferences. The local inhabitants should also be a part of this campaign.

Acknowledgments The main researcher is grateful to the International Foundation for Science IFS, Sweden, (Grant Award W/5074-1), for providing funds needed for the execution of this project. The support and contribution of the host institution, Nnamdi Azikiwe University, Awka, Nigeria, is also acknowledged. The efforts of the field and laboratory party which comprises some colleagues, final year undergraduate and post-graduate students of the host institution are also very much appreciated.

\section{References}

Busby JP, Peart PJ (1997) Azimuthal resistivity and seismic measurements for the determination of fracture orientations. Geol Soc Lond Eng Geol Spec Publ 12:273-281

Earle J, Callaghan T (1998) Impacts of mine drainage on aquatic life, water uses, and man-made structures. In: Brady BC, Kania T, Smith WM, Hornberger RJ (eds) Coal mine drainage prediction and pollution prevention in Pennsylvania: pennsylvania department of environmental protection, pp 1-22
Egboka BCE (1985) Water resources problem of Enugu area, Nigeria, vol 153. IAHS Publishers, Wallingford, pp 95-106

Ememcheta NC (2013) Geology and hydrogeochemistry of Okpara coal mines and environs, Enugu State, Nigeria, unpublished BSc thesis. Nnamdi Azikiwe University, Awka

Ezeigbo HI, Ezeanyim BN (1993) Environmental pollution from coal mining activities in the Enugu Area, Anambra State, Nigeria. Mine Water Environ 12:53-62

Folk RL, Ward WC (1957) A study of the significance of grain size parameter. J Petrol 37:327-354

Gray NF (1996) Environmental impacts and remediation of acid mine drainage: a management problem. Environ Geol 30:62-67

Habberjam GM (1967) On the application of the reciprocity theorem in resistivity prospecting. Geophysics 32:918-919

Hem JD (1985) Study and interpretation of the chemical characteristics of natural water. US Washington DC: geological survey water supply paper 2254, p 263

Kogbe CA (1974) The cretaceous and palaeogene sediments of Southern Nigeria. In: Kogbe CA (ed) Geology of Nigeria. Elizerbertan Publication, Lagos, p 538

Murat RC (1972) Stratigraphy and paleogeography of the lower tertiary in Southern Nigeria. In: Dessauvagie TFJ, Whiteman AJ (eds) African geology. University of Ibadan Press, Ibadan, pp 251-276

Nwajide CS (2013) Geology of Nigeria's sedimentary basins. CSS Bookshop, Lagos

Obaje NG (2009) Geology and mineral resources of Nigeria. Springer, New York 222p

Obiadi II, Onwuemesi AG, Anike OL, Ajaegwu NE, Anakwuba EK, Nwosu CM, Akpunonu EO, Onuigbo EN, Onuba OL (2013) Determining subsurface fracture characteristics from azimuthal square array resistivity survey at Igarra, Nigeria. Pure Appl Geophys 170(5):907-916

Raghunath R, Sreedhara Murthy TR, Raghavan BR (2001) Spatial distribution of $\mathrm{pH}, \mathrm{EC}$ and total dissolved solids of Nethravathi river basin, Karnataka, India. Poll Res 20:413-418

Singh G, Mridula B (1985) Bacterial formation of acid mine drainage, causes and control. J Sci Ind Res 44:478-485

Stumm W, Morgan JJ (1996) Aquatic chemistry. Wiley, New York, p 1022

Utom AU, Odoh BI, Egboka BCE (2013) Assessment of hydrogeochemical characteristics of groundwater quality in the vicinity of Okpara coal and Obwetti fireclay mines, near Enugu town, Nigeria. Appl Water Sci 3:271-283 